\title{
Ni complot judeo-masónico ni filosemitismo: la ambivalencia discursiva del encuentro cultural hispano-judío en las logias norteafricanas*
}

\author{
Valeria Aguiar Bobet ${ }^{1}$ \\ Universidad Jaume I \\ vaguiar@uji.es
}

RESUMEN: La documentación requisada a las logias masónicas norteafricanas por el franquismo justificaría el complot judeo-masónico que motivó la represión de los componentes de la orden. No obstante, la realidad hispano-judía en esta masonería, así como sus objetivos y proyectos, divergían sustancialmente de tal incriminación. En este estudio revisaremos la presencia judia en las logias españolas de Marruecos para dirimir si fue determinante en la construcción del discurso masónico español imperante hasta la II República y, si, además, estuvo condicionada por la (re) construcción de las identidades de españoles y judios en un contexto marcado por las teorías evolucionistas, racialistas, el filosefardismo, el antisemitismo y el sionismo. Para ello, a través de la documentación de las logias magrebies cuantificaremos y calificaremos el «encuentro cultural» hispano-judio con el objeto de detectar las particularidades, posibles fricciones y aquiescencias de su interacción que, consideramos, van más allá del filosemitismo masónico, del discurso de las logias y del catastrofista mito del complot.

PALABRAS ClAVE: masonería; colonialismo; protectorado español de Marruecos; relaciones hispano-judías; identidades; filosefardismo.

* La documentación consultada pertenece al Centro Documental de la Memoria Histórica, Salamanca, (CDMH) y el Centre des Archives Diplomatiques et Affaires Étrangères, France (CADAE).

${ }^{1}$ ORCID iD: https://orcid.org/0000-0001-7343-5169.

Copyright: (C) 2019 CSIC. Este es un artículo de acceso abierto distribuido bajo los términos de una licencia de uso y distribución Creative Commons Reconocimiento 4.0 Internacional (CC-BY 4.0) 
Neither judeo-masonic conspiracy nor philosemitism: the discursive ambivalence of the Hispano-Jewish cultural encounter in North African lodges

ABSTRAC: Documentation requisitioned by the Franco regime from North African masonic lodges was used to justify the accusation of a Jewish-Masonic conspiracy, leading to repression of members of the institution. However, the Spanish-Jewish reality of these freemasons, their goals and projects were far from warranting such incrimination. This study reviews the Jewish presence in Spanish lodges in Morocco to determine whether it was decisive in the construction of the Spanish Masonic discourse that prevailed until the Second Republic, and whether, in addition, it was conditioned by the (re)construction of Spanish and Jewish identities in a context marked by evolutionary theories, philosephardism, antisemitism and Zionism. Consequently, documentation from Maghrebi lodges are used to quantify and gauge the Hispanic-Jewish "cultural encounter" to detect particularities, possible frictions and acquiescence in this interaction which we consider go beyond Masonic philosemitism, lodge discourse and the catastrophist myth of conspiracy.

KeY WORDS: masonry; colonialism; Spanish Morocco Protectorate; Hispanic-Jewish relations; identities; philosephardism.

CÓMO CITAR ESTE ARTÍCULO/CITATION: Aguiar Bobet, Valeria, «Ni complot judeo-masónico ni filosemitismo: la ambivalencia discursiva del encuentro cultural hispano-judío en las logias norteafricanas», Hispania, 79/261 (Madrid, 2019): 189-219. https:// doi.org/10.3989/hispania.2019.007.

\section{INTRODUCCIÓN}

«Contubernio», «complot», «conspiración» fueron los términos que explicaron la vinculación entre masones y judíos durante gran parte del siglo XX. Y, quizás, el caso más pintoresco de estas interpretaciones fue la versión franquista: décadas de antimasonería y antisemitismo plagaron el imaginario español hasta tal punto que la retórica del régimen pudo, desde el inicio del «Glorioso Movimiento Nacional» en 1936, justificar y legitimar su existencia. Los archivos requisados a las logias norteafricanas en el debut de la represión oficial a la masonería contenían numerosos proyectos y escritos laicistas, anticlericales, ideas liberales y «anti-patriotas» pero, sobre todo, un sin fin de documentación en contra del fascismo y en apoyo a los judíos perseguidos en Europa. El mito complotista de los «nacionales» no pudo quedar más satisfecho. Y es que la masonería española durante el siglo $\mathrm{XX}$, posicionada «siempre» «en defensa del oprimido»², consigna básica de sus

\footnotetext{
2 «Los francmasones ante el mundo», Boletín Oficial y Revista Masónica del Supremo Consejo del Grado 33 para España y sus dependencias, septiembre-diciembre 1935: 413-414, Biblioteca Nacional de España, Hemeroteca Digital, número 9/35.
} 
preceptos más elementales, se caracterizaría no solo por tales iniciativas filosemitas, sino por otra particularidad más sustancial. En las listas ${ }^{3}$ de masones, obtenidas a partir de los archivos incautados - que incluían cuantiosos errores corregidos ahora en nuestra investigación-, se comprobó que de los 1000 componentes masones existentes durante la etapa republicana, la suma de judíos versaba entre $168-170^{4}$, mientras que los musulmanes se mantendrían en 27. Es más, en todas las logias había, al menos, un integrante judío, aunque se arraigaron con mayor frecuencia en los núcleos urbanos más importantes del territorio 5 .

No quedaba ninguna duda: la existencia de judíos en las logias resultaba la prueba irrefutable de la existencia del complot. Tales pruebas justificaban no solo la vinculación completa entre la masonería y el judaísmo, sino también su ideología anticlerical y antipatriótica identificadas como anti-catolicismo y anti-españolismo lo que les enfrentaba directamente con las bases sustentadoras de la nueva identidad nacional. Así se demuestra en la memoria ${ }^{6}$ citada en 1938 por el secretario de la Alta Comisaría de Marruecos, Antonio Yuste, y el delegado del Estado para la Recuperación de Documentos, Marcelino de Ulibarri, donde constaba que la orden perseguía «de una manera tenaz la Religión de Cristo, protegiendo a los judíos» y se valía del judaísmo para «conseguir una nueva civilización que le permita a este último llevar a cabo su venganza por la expulsión de que fue objeto por los Reyes Católicos»?

No obstante, la realidad hispano-judía en las logias norteafricanas, así como sus objetivos y proyectos, divergían sustancialmente de esta incriminación. En Marruecos, territorio colonizado oficialmente por Francia y España en 1912 bajo la fórmula de protectorado, la mayoría de la población era de origen árabe y bereber, seguida por los semitas, especialmente sefardíes y askenazíes. La población española, francesa y de diversa nacionalidad europea era menor pero muy representativa por ser los «protectores» en la balanza colonialista. De este modo, las tres culturas por antonomasia convergieron en Marruecos ofreciendo a las logias españolas la oportunidad de configurar un «ideal masónico colonial $\rangle^{8}$ en base a esta convivencia. La retórica del ideal partía de los propios preceptos de la modernidad ilustrada en la que nació la masonería, que pueden resumirse en el universalismo, el cosmopolitismo, la confraternidad y la tolerancia a todas las religiones. También del canon colonial africanista, que otorgaba el derecho legítimo a España de colonizar el Magreb por la identidad

\footnotetext{
3 Se conservan numerosos registros, CDMH, SE Masonería A, legajo 357, exp. 390-391.

4 AGUIAR BOBET, 2017a: 494-496.

5 Tánger, Tétuán, Larache, Casablanca y Fez.

${ }^{6}$ Memoria redactada a base de los documentos y antecedentes masónicos recogidos en las distintas logias (...) de Marruecos, CDMH, SE Masonería A, legajo 769, exp. 1. PAZ SÁNCHEZ et al., 9 (Melilla, 1987): 83-94.

${ }^{7}$ Memoria..., CDMH, SE Masonería A, legajo 769.

8 AGUIAR BOBET, 2017a, vol. 2: 493-507.
} 
compartida entre judíos, españoles y musulmanes evocando a una idealizada y distorsionada edad de oro andalusí. Y, por último, de la propia percepción de Marruecos como el «paraíso perfecto» para el desarrollo del ideal por su situación multicultural y por su condición «incivilizada», al menos según las teorías evolucionistas de la época. En este espacio la masonería partiría desde cero en su misión de construir una sociedad bajo sus preceptos que derivaría, en última instancia, en la convivencia igualitaria entre culturas. El ideal masónico, de este modo, terminaría materializándose en un proyecto "cosmopolitizador»" cuyo objetivo era la cultura de la tolerancia y la integración y aculturación total (al menos en teoría) de los tres grupos sin distinción.

Sin embargo, la consecución del ideal estuvo extralimitada desde y por las propias barreras conceptuales y socioculturales del canon colonial y la política del protectorado. Los estereotipos y clichés entre culturas, así como la ambivalencia en la que se adscribían las diferentes identidades en (re)construcción y de España y la patria española como metrópoli y protectora incuestionable, se imponían y condicionaban el discurso y el proyecto, convirtiéndolo desde sus mismas bases en una utopía. Los judíos masones, en este sentido, asumieron el discurso y el proyecto masónico laborando en su favor, tal y como demostramos en un trabajo anterior ${ }^{10}$, pero también, diferentes barreras y fracturas culturales extralimitaron y determinaron su participación en él.

En esta ocasión, nuestro propósito radica en revisar, retrospectivamente, la presencia judía en las logias españolas norteafricanas para estipular, primero, si dicha presencia fue determinante en la construcción del discurso masónico imperante hasta la II República, es decir, si los componentes judíos de las logias fueron también sus significantes y no meros receptores ajenos a él. Y, segundo, si su configuración estuvo relacionada directamente con la (re)construcción de las identidades, tanto de españoles como de judíos, en un contexto marcado por las teorías evolucionistas, racialistas, el descubrimiento andalusí de España, el filosefardismo, el antisemitismo y el sionismo. «Resituar» a los judíos en el (o por el) discurso masónico, es decir, reconsiderar su posición como sujetos participativos y significantes y no como ajenos o externos a él, se vuelve esencial para alejarnos de conclusiones y categorías maniqueas propias del mito complotista o su versión contraria, la exaltación de la orden, que más que ofrecer luz sobre la historia, la reducen, simplifican y obstaculizan ${ }^{11}$.

\footnotetext{
9 AGUIAR BOBET, 2017b, tomo V: 144-568.

10 AGUIAR BOBET, 2017a, vol. 2: 493-507.

${ }^{11}$ La conformación de cualquier discurso está asociado a los individuos que lo significan y le otorgan un sentido o interpretación concreta. Los actores no solo se benefician de él o lo asumen, sino que primero lo (re)construyen y adaptan a partir de significados, motivaciones y fines concretos. Los discursos, en este sentido, son dinámicos, se amoldan y traducen constantemente por lo que su estudio nos permite definir mejor las fronteras o fusiones culturales entre diferentes grupos implicados. Los procesos de encuentro e interacción - que engloban actitudes,
} 
En definitiva, a través de la documentación de las logias magrebíes cuantificaremos y calificaremos el «encuentro cultural» hispano-judío con el objeto de detectar las particularidades, posibles fricciones y aquiescencias de su interacción, que consideramos, van más allá del filosemitismo masónico, del discurso de las logias y del catastrofista mito del complot. No obstante, primero debemos establecer el marco histórico e ideológico en el que se conformaron.

\section{¿IDENTIDADES O FINES COMUNES? RETROSPECTIVA DE LAS RELACIONES HISPA- NO-JUDÍAS}

En España, la «otredad» del judío ha desempeñado a través de los siglos un papel central en la construcción de la imagen que «los cristianos» poseían de sí mismos. Fueron el receptáculo físico, psicológico y emocional de la proyección colectiva de todos aquellos atributos considerados esencialmente negativos desde la Edad Media hasta la actualidad ${ }^{12}$. Pero la construcción de este concepto socio-racial, denominado casticismo, no ha sido homogénea ni ecléctica. Estigmatizado fundamentalmente a raíz de las nuevas fórmulas identitarias del Estado-nación moderno que se sustentaban en la etnicidad-cultural, la lengua española y el catolicismo ${ }^{13}$, en el siglo XIX, en pleno descalabro colonial, sufriría un cambio sustancial. España se enfrentará a un proceso dicotómico en la reconstrucción y redefinición de su identidad nacional en el que los judíos y también musulmanes vuelven a situarse en el centro de esta reflexión. En un contexto en el que otros estados europeos estaban interesados por «Oriente» como mecanismo de consolidación de su dominio sobre el mundo colonial, la nación española incentivará y reorientará sus intereses al norte de África, donde precisamente se encontraban el grueso de los descendientes de las diásporas íbero-judías e íbero-musulmanas ${ }^{14}$. El orientalismo de corte española se convertía así en «africanismo», mientras que el casticismo era desbancado por el filosefardismo, un movimiento sociopolítico y cultural de ciertas capas intelectuales y militares de la población cuyo objeto era promover el acercamiento cultural y colonial a la diáspora sefardí, fundamentalmente en el Mediterráneo musulmán. Tal ambivalencia en el imaginario español se acrecentaría, sobre todo, durante el periodo republicano, cuando el Estado impulsará el debate del filosefardismo y considerará diversas políticas pluralistas al respecto. Quedó

\footnotetext{
mentalidades y valores-, sus diferentes formas de expresión y su correspondiente significado simbólico, permiten al investigador desligarse de la irrealidad de las categorías y conceptos y centrarse en las fisuras, barreras y ambivalencias que presentan. BURKE, 2010: 63-72.

12 ÁLVAREZ CHILLIDA, 2011: 123-159.

13 ALONSO GARCÍA, 2007.

14 OJEDA MATA, 20/2 (2015): 39.
}

Hispania, 2019, vol. LXXIX, nº 261, enero-abril, págs. 189-219, ISSN: 0018-2141, e-ISSN: 1988-8368 https://doi.org/10.3989/hispania.2019.007 
constancia de ello en la propia Constitución de 1931, concretamente en el artículo 23 , donde se establecía que una ley facilitaría la nacionalidad «a personas de origen español que residan en el extranjero», incluyendo así también a los sefardíes no marroquíes. Pero la ley prevista nunca llegó a aprobarse ${ }^{15}$, es más, los planes o propósitos nunca pasaron de las buenas intenciones y casi nada se hizo en el terreno cultural, educativo o comercial y menos aún en la política de nacionalizaciones. Al contrario, el resultado fue el incremento de la imagen casticista por medio de los círculos del catolicismo tradicionalista e integrista aún más partidarios del antisemitismo, que a su vez se nutría de un frente europeo fascista más feroz. No es de extrañar que la popular obra Los Protocolos de los sabios de Sión tuviera en España doce ediciones entre 1932 y $1936^{16}$.

Sin embargo, las ambivalencias en la percepción de los judíos en el imaginario español y en la reflexión identitaria de la nación difirieron respecto a las de los musulmanes. El «judío» era un pueblo intermedio entre los «indígenas $\rangle^{17}$ - calificativo con el que acuñaban a los musulmanes - y los protectores, abanderados de la civilización occidental, que estaban situados en los estratos más altos del escalafón evolucionista. Es decir, los judíos quedaban excluidos de la condición de locales ${ }^{18}$, pues no se consideraban marroquíes per $s e$, al contrario, eran «hebreos» o «israelitas» en alusión a su condición étnico-religiosa, por lo que el discurso colonial podría ser más efectivo si se les comprometía a través de él. Eran, además, una minoría respecto a la población musulmana. Se encontraban sometidos a la protección que dispensaba la $\mathrm{dihm}$ mah, lo que suponía en la práctica cierta discriminación por parte de la administración marroquí19 ${ }^{19}$ pero que, a su vez, serviría de pretexto a los colonos españoles para convertirles en el instrumento perfecto en su objetivo de ocupar Marruecos. Nada nuevo, de hecho, puesto que las élites de las minorías religiosas, comúnmente judíos, ejercieron funciones de mediadoras comerciales entre las colonias y sus metrópolis, principalmente como agentes comerciales en actividades de importación y exportación, así como en la función de intérpretes de las legislaciones diplomáticas extranjeras. No obstante, en el caso español, recurrir al tropo andalusí era, por un lado, un argumento adicional para dar mayor legitimidad a las aspiraciones coloniales españolas frente a las

15 Un decreto de 1924 concedía un plazo para solicitar la nacionalidad española a varios miles de sefardíes protegidos por España; posteriormente se dificultó su implementación y muchos no llegaron a completar los trámites. ÁLVAREZ CHILLIDA, 2011: 132.

16 ÁLVAREZ CHILLIDA, 2011: 137.

17 En la época colonial, «indígena» era el que vivía en un estadio inferior y al que era preciso civilizar. MATEO DIESTE, 20/2 (2015): 108.

18 OJEDA MATA, 20/2 (2015): 40-41.

19 Antes de la colonización, el estatus de los judíos en tierra musulmana venía definido por la condición de «protegido» o dimmi, a cambio del pago de un impuesto y de ciertas exclusiones. MATEO DIESTE, 2015: 109. 
ambiciones de las demás potencias occidentales, y por otro, una forma práctica y conciliadora para obtener la cooperación de los propios sefardíes en el proyecto colonial español ${ }^{20}$. El resultado fue que ciertas élites judías - y también algunos notables musulmanes - gozarían de la protección europea, entre ellas, la española ${ }^{21}$, y que algunos de los individuos protegidos adquirirían la nacionalidad de sus potencias protectoras desde $1869^{22}$.

Junto a ello, las élites sefardíes de las ciudades magrebíes se beneficiarían de la colonización cuando, en 1912, con motivo de la guerra de Marruecos, apoyaron a los españoles en detrimento de los intereses políticos internos del Imperio marroquí. En este sentido, aprovecharon la influencia europea sin menosprecio del propio país que les acogió desde la expulsión del territorio hispano en 1492. ¿Qué podía significar la colonización española para su comunidad étnico-cultural? Lo que el propio canon colonial les ofrecía: el contacto directo con las naciones-estado «civilizadas» de Europa, nuevas perspectivas y dinamismo económico, el fin de la exclusión social y cultural a la que se habían visto sometidos desde las diásporas y de su situación marginal en un territorio de mayoría musulmana pero, sobre todo, la perspectiva de una nueva identidad histórica que, basada en el pasado compartido o en una instrumentalización política concreta, les ofrecería mayores ventajas a nivel internacional. Además, las propias élites respondieron favorablemente a las tesis que defendía el filosefardismo, creando, a su paso, varias instituciones españolizantes: las Asociaciones Hispano-hebreas, la Casa Universal de los Sefardíes, etcétera. De este modo, la instrumentalización de las identidades compartidas no provino únicamente de la política española, también formaba parte de los intereses de estas élites.

Sin más preámbulos —ya trabajados por otros especialistas - , no debemos subestimar la importancia otorgada desde diferentes círculos intelectuales a este proceso denominado por Martín-Márquez «segunda oleada de construcción nacional $»^{23}$, que coincide, no casualmente, con la pérdida de las colonias americanas y asiáticas prolongadas hasta 1898 . Ya sea por puro interés partidista, imperialista o por el deseo regenerador de los problemas de la nación, el pasado común compartido y las fronteras culturales difusas supusieron resultados drásticos en la configuración de las identidades que entraban en juego. $\mathrm{Si}$ a eso añadimos que la propia noción de judío, español y cristiano son construcciones híbridas per se, al menos desde un análisis retrospectivo, comprobamos

20 OJEDA MATA, 2009: 265-275.

${ }^{21}$ ALONSO GARCÍA, 2007.

${ }^{22}$ Estar bajo la protección de un país occidental significaba escapar de la jurisdicción del sultán (especialmente tributaria). Suponía un evidente privilegio. MARTÍN CORRALES, 2013: 93-94.

${ }^{23}$ MARTÍN-MÁRQUEZ, 2011. 
la complejidad del problema expuesto. Y si añadimos la variable definitiva que ocupa nuestro estudio, es decir, la masonería y los masones, ya fuesen judíos o españoles, corroboraremos la necesidad de abordar los encuentros culturales en una organización esencialmente occidental, ilustrada y universal, con toda la carga conceptual y significativa que esto pudiera tener.

\section{EL «ENCUENTRO CULTURAL» EN LAS LOGIAS MARROQUíES}

Entre todas las posibilidades que ofrecen los estudios de la masonería, debemos diferenciar dos aspectos. Por un lado, el discurso masónico en sí, que parte de las Constituciones de Anderson (1723) y de las bases ideológicas de cada logia o grupos de logias (obediencias nacionales o regionales) - que hacen que hablemos de masonerías en su significado plural-. Y por otro, los espacios en los que se desarrolla la actividad masónica, las logias y los templos, y que son, esencialmente, los lugares donde se desarrollan los encuentros entre individuos que comparten, en teoría, el mismo discurso y la misma ideología al respecto de la masonería y del orden social que esta propone. Las logias, en este sentido, han sido definidas como espacios de sociabilidad, espacios heterotópicos o, simplemente, espacios consagrados a los rituales y ceremonias propias de la institución.

En el primero de los sentidos propuestos, la masonería norteafricana se definía bajo el ideal masónico colonial y su proyecto cosmopolitizador, cuyas bases provenían del canon colonial africanista y la redefinición de la identidad del español por el pasado andalusí compartido, a lo que se le sumaba el apoyo directo de la comunidad judía en el proceso colonialista a partir del régimen de protecciones. Como pretexto y en base a la identidad o fines compartidos resultantes de esta nueva praxis narrativa, el ideal masónico colonial español empezaría a hilvanarse desde las primeras logias constituidas en el territorio marroquí. Y la inaugural prueba de ello fue la inclusión, en sus primeros cuadros, de la presencia judía. Presencia que, en la masonería republicana, transfigurada por el franquismo en su mítico complot, no pudo, ni podía ser, espontánea. Los datos adquiridos a partir de diferentes «cuadros lógicos» ${ }^{24} \mathrm{de}$ las logias españolas que se constituyeron en Marruecos desde finales del siglo XIX hasta 1936, así como el resto de la documentación conservada en el archivo de Salamanca, nos han permitido establecer un balance cuantitativo y cualitativo de esta presencia, pero también del encuentro hispano-judío consiguiente. Más allá de resaltar la importancia numérica del sector que tomamos como muestra, nuestro propósito es reflexionar sobre aquellos elementos y

${ }^{24}$ Así se denominan las listas de miembros en la masonería.

Hispania, 2019, vol. LXXIX, n 261, enero-abril, págs. 189-219, ISSN: 0018-2141, e-ISSN: 1988-8368 https://doi.org/10.3989/hispania.2019.007 
características que llevaron a la creación del discurso masónico de estas logias y cómo este estuvo condicionado y extralimitado por las identidades en (re) construcción de judíos y españoles.

\section{Cuantificación de la presencia judeo-masónica}

La documentación conservada de las primeras logias españolas constituidas en Marruecos es escasa, pero se conservan parte de las cartas patentes, cuadros lógicos, correspondencia, memorias...que nos permiten reconstruir sus historias y cuantificar la presencia judía en ellas a lo largo de su recorrido cronológico y en relación al número total de componentes. No obstante, al ser numerosas y abarcar un espacio de tiempo considerable (1881-1936), hemos establecido los porcentajes de cada taller relativos a esta representación, marcando la diferencia espacio-temporal para brindar mayor inteligibilidad cualitativa que cuantitativa ${ }^{25}$. Por ello, hemos divido la exposición de datos en tres gráficos. En el primero (I) se incluye el porcentaje total de judíos de los talleres antes de la institucionalización del protectorado (1912). En el segundo, las logias que continuaron su actividad después de iniciada dicha oficialización y otras nuevas instituidas por el resto del país cuya vida abarcaría, más o menos, hasta 1930. Y en el último, los talleres instaurados durante la II República, periodo que, por ser un punto de inflexión en la historia de España y por ser el primer régimen político que autorizó y legalizó la masonería, además de otros factores, merece la distinción analítica pertinente. En ninguno de los casos, sin embargo, hemos especificado al porcentaje sefardí26 entre los judíos contabilizados, tanto porque no siempre aparece reflejada esta condición en la documentación, como por la propia extensión del tema que nos ocupa. Nuestro interés versa, en esta ocasión, en la presencia judía general y su interacción con los españoles en las logias.

Tal y como indica el cómputo temporal del gráfico (I), en Marruecos, la institución de talleres masónicos españoles precedió a la colonización oficial de la metrópoli: la primera logia constituida fue Luz de Marruecos en Tetuán en $1881^{27}$, veinte años antes de la oficialización del protectorado (1912). No obstante, hasta 1888 no se fundarán talleres de un modo más sistemático debido,

${ }^{25}$ Los cuadros lógicos se encuentran en las carpetas correspondientes a cada logia situadas en el Fondo del Norte de África del CDMH. Por su elevado número, no citaremos en este apartado sus referencias concretas, tan solo cuando se citen documentos.

${ }^{26}$ OJEDA MATA, 2013: 193-194, establece que la participación de los sefardíes en la masonería española asciende a 3,27\%.

27 Esta fecha hace mención a la primera logia española que conserva la documentación sobre su constitución. No obstante, existieron otras logias en Tánger desde, al menos, 1880 aunque solo conocemos su mención nominativa. 
GrÁfico I. Porcentaje de judíos en las logias españolas de Marruecos (1881-1912)

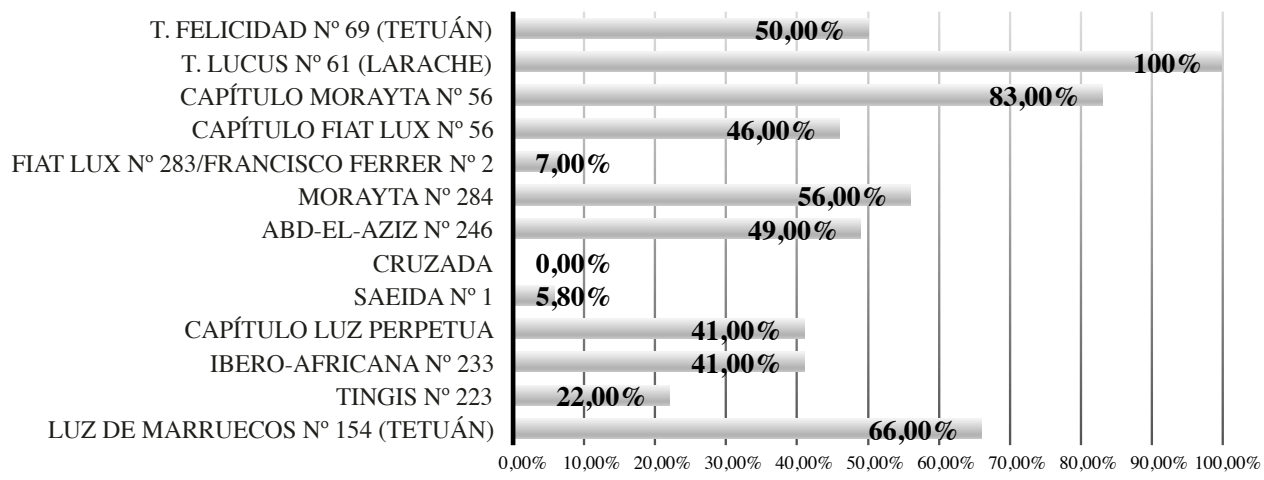

Fuente: creación propia.

precisamente, a la importancia, según indica el Boletín del Gran Oriente Nacional de España (GONE) «que está tomando Marruecos para España y el gran número de durmientes masones en este territorio» ${ }^{28}$. Y Tánger será la ciudad que albergará la mayor parte de estos talleres, razón por la que no se especifica este ítem en el gráfico, salvo en el primer caso. Tánger era una ciudad abierta y cosmopolita, donde residía el cuerpo diplomático europeo acreditado ${ }^{29}$ por lo que tenía las mejores condiciones para servir de centro de implantación - y difusión - de la francmasonería ${ }^{30}$. No es anecdótico que se configure aquí en 1890 y por iniciativa de los masones españoles, el Gran Oriente de Marruecos (GOM), que además de trabajar por la regeneración de la masonería peninsular con autonomía geográfica y jurisdiccional propia, incluiría logias de varios países europeos (Inglaterra, Francia y otros estados americanos), pero también a los grupos religiosos oriundos que representaban la mayoría de la población del territorio, los musulmanes marroquíes.

Los datos expuestos así lo demuestran: tres de las 13 logias constituidas en este periodo presentan mayoría de judíos entre sus integrantes, destacando especialmente el primer taller fundado, Luz de Marruecos, con un 66\%: de sus 12 miembros, 7 eran judíos, uno de los cuales fue su venerable maestro. Pero también la logia Morayta n. 284 del Gran Oriente Español (GOE) (56\%) y el capítulo del mismo nombre (86\%) presentan una mayoría indiscutible. En el caso de la logia, sin embargo, es más representativo porque el número máximo de componentes siempre fue superior al de otros talleres: en 1909, de 67 miembros, 40 eran judíos, cifra que se incrementaría en 1912 a 47 de 88. Su membresía no

\footnotetext{
28 Unión Ibérica-Africana al GONE, 1888, CDMH, SE Masonería A, legajo 771.

29 LÓPEZ GARCÍA, 5/6 (2012).

30 MOGA ROMERO, 2004: 73.
} 
dejará de crecer al mismo tiempo que la presencia judía con un porcentaje de 75 y con máximas que llegaron en 1915 a 102 integrantes, 71 de ellos, judíos. Será el taller tangerino más numeroso de estas fechas y el más activo y duradero (hasta 1932). Reconocido como la «logia hebrea» será el responsable de la fundación de diversos talleres en el resto del territorio marroquí.

De todos modos, tampoco debemos subestimar los datos expuestos sobre los demás talleres: cuatro de ellos presentan un porcentaje en torno al $49 \%$ de presencia judía. Abd-El-Aziz n. ${ }^{\circ}$ 246, por ejemplo, se fundaba en 1892 con 6 judíos de 7 componentes y llegaría en 1906 a 24 de 55. Esta será, además, la única logia que sobrevivirá al GOM, representado también por los talleres Cruzada, Saeida n. ${ }^{\circ}$, Unión Ibero-Africana n. ${ }^{\circ} 233$ y Tingis n. ${ }^{\circ} 223$ que manifiestan, salvo las dos primeras, un porcentaje destacado de judíos en sus filas, 41 y 22 respectivamente, y que fueron, además, las logias que debutaron entre los años 80 y 90 del siglo XIX marcando las bases ideológicas que nutrieron a sus descendientes. En un trabajo leído en 1898 en Abd-El-Aziz, perteneciente probablemente a un miembro visitador o inspector del GONE, tal deber se establecía en los términos siguientes:

\begin{abstract}
... qué hermosa misión la de ese taller hallándose como se halla enclavada en la ciudad más civilizada del imperio Marroquí! A vosotros y a ella toca llevar el progreso y la cultura a millones de hombres que en él yacen envueltos en las tristes sombras de la ignorancia y la barbarie. Si sabéis realizar vuestra misión, vuestros nombres pasarán al libro inmortal de las historias y las generaciones futuras os bendecirán por haber sido los primeros en abrir en ese país, los derroteros que han de conducirle a la vida de los pueblos cultos. A vosotros toca inundar de masones y de logias todo el Imperio Marroquí (...) podéis ser la base y la fuente de todo el ese país, si sabéis daros buena traza para ello ${ }^{31}$.
\end{abstract}

Esta retórica discursiva en la que regenerar España y civilizar Marruecos eran las máximas premisas de los judíos y españoles masones de Tánger, no se convirtieron en una mera muestra dialéctica. La expansión masónica protagonizada por la logia Morayta al final de la primera década del siglo XX en dos enclaves con mayor influencia española y con comunidades sefardíes importantes, Larache y Tetuán, son el mejor ejemplo de ello a pesar de la corta vida que tuvieron (Lukus en 1907 y Felicidad n. ${ }^{\circ} 69$ en 1913). Y aunque la cifra de los triángulos sea considerada (50 y 100\%) apenas presentan actividad debido a las guerras de Marruecos acontecidas desde 1912 a 1927 y al porcentaje ínfimo de españoles que aún no habían colonizado del todo la zona. No obstante, la existencia de ambos talleres marcaría el inicio de la expansión de la orden por el recién configurado protectorado. Expansión que, además, inauguraría nuevas

\footnotetext{
${ }^{31}$ Abd-El-Aziz, CDMH, SE Masonería A, legajo 770, exp. 8.
} 
GRÁFICo II. Porcentaje de judíos en las logias españolas de Marruecos (1913-1930)

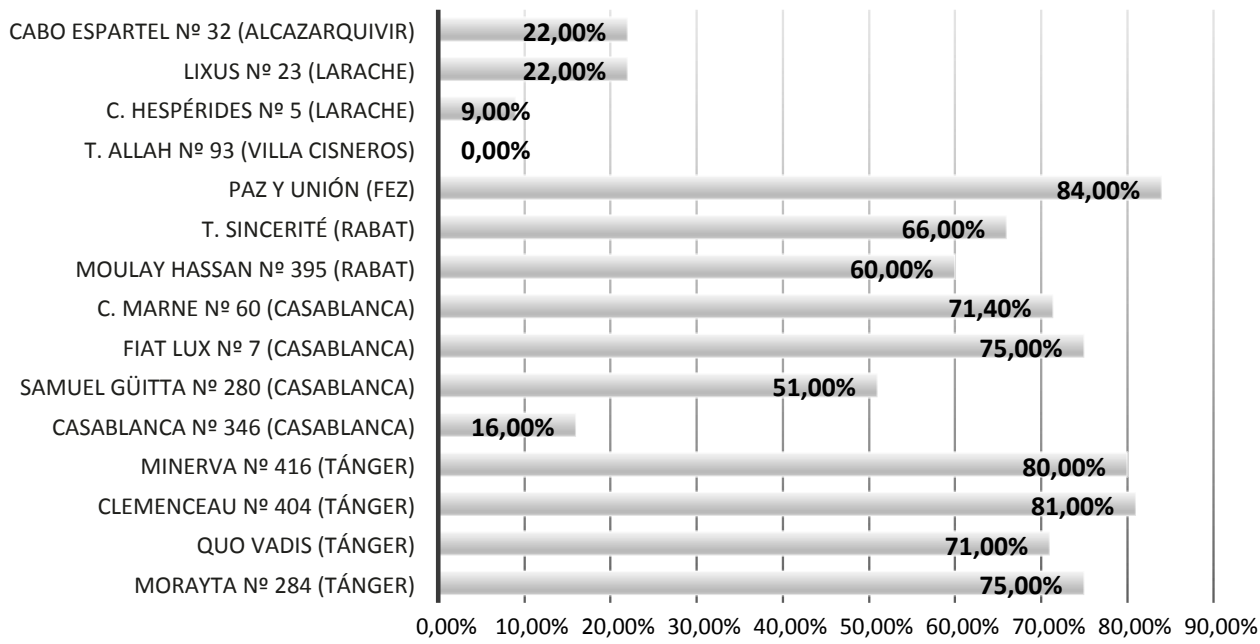

Fuente: creación propia.

logias en algunos núcleos urbanos de la parte administrada por los franceses en el reparto de Marruecos (gráfico II).

En este sentido, la gráfica (II) confirma que, los talleres tangerinos de nueva planta presentan, al igual que sus predecesores, una mayoría absoluta de judíos en sus cuadros con un porcentaje entre el 75 y el 81\%. A pesar de ello, constituidos entre 1916 y 1925, verán obstaculizadas su corta vida (apenas dos años) por las vicisitudes históricas de los países protectores. Nos referimos a la I Guerra Mundial, la «crisis» de la Restauración española que llevó a la dictadura militar de Primo de Rivera, las guerras del Rif y, de nuevo, el desmoronamiento del régimen político español que daría paso a la etapa republicana. Por otro lado, junto a estas desavenencias, destacará la persecución de la masonería por parte del régimen primorriverista que provocará un descenso de las iniciaciones en las logias, así como la retirada de muchos de sus integrantes. Entre los judíos, esta retirada estuvo marcada por la emigración a la zona del protectorado francés. Directos de Tánger, muchos de ellos comerciantes que nutrían las logias de dicha ciudad, trasladaron su hábitat y su ideal masónico colonial hacia Casablanca, Fez, Rabat y Marrakech. Estos desplazamientos también se debían al auge económico de las ciudades ocupadas por los franceses, cuyo impulso fue mayor que las relativas a la zona española que presentaban más bien una economía de subsistencia. Es cierto que el territorio adjudicado a España en 1912 siempre tuvo menos posibilidades de desarrollo ${ }^{32}$ y no será

\footnotetext{
${ }^{32}$ AZIZA, 2013, vol. 1: 127-148.
} 
hasta la II República cuando empiece a crecer su importancia. Prueba de ello será que la sede de la Gran Logia Regional de Marruecos (GLRM) de esta última etapa de la historia de la masonería será en Tetuán y no en Tánger como en las dos ocasiones anteriores ${ }^{33}$. La segunda de ellas, por cierto, sería iniciativa de una de las logias más prominentes de Casablanca, Samuel Güitta, que adoptaba el nombre del distinguido doctor judío de la cuidad tangerina, quien había sido venerable maestro de Morayta desde su constitución en 1905.

De este modo, la iniciativa de los masones y la consecución de su alta misión se fueron desplazando hacia el protectorado francés donde, como novedad, no siempre fueron mayoría los componentes con nacionalidad española. Por ejemplo, la logia Moulay Hassan n. ${ }^{\circ} 395$ de Rabat se compondrá de ingleses, italianos, franceses y marroquíes. De los 6 judíos que integran sus filas, solamente uno es marroquí $\mathrm{y}$, el resto, ingleses y franceses ${ }^{34}$. Esto explica, a su vez, las constantes y buenas relaciones que, por lo general, mantenían los talleres de Rabat, Casablanca y Fez con las logias francesas, tal y como demuestran sus actividades conjuntas. No obstante, el grueso de dicha composición será otra vez favorable para la comunidad étnico-religiosa judía. $\mathrm{Si}$ atendemos a los datos expuestos, los talleres situados en las ciudades de la zona francesa presentan más de un $50 \%$ de integrantes judíos, destacando, sobre todo, los de Casablanca. Samuel Güitta contará con un máximo de 135 miembros en 1923 con una relación de 64 judíos, año en el que se fundará también Fiat Lux n. ${ }^{\circ} 7$ con 12 judíos de 13 integrantes totales, incrementando sus cifras en 1926 a 23 de 37. Esto nos lleva a la salvedad de Casablanca n. ${ }^{\circ}$ 346 con apenas un $16 \%$ de presencia judía a lo largo de su historia, que perdurará incluso, a la disolución de la regional de Tetuán durante la etapa republicana. Sin embargo, sus datos son característicos del comportamiento de los individuos. Como en la etapa precedente con Abd-El-Aziz y Morayta, y salvo en casos concretos, los componentes judíos suelen iniciarse o afiliarse en las logias donde hay más miembros de su mismo grupo étnico-cultural, dando la impresión de que algunas logias eran más «hebreas» como Samuel Güitta y Morayta y otras, más «cristianas» como Casablanca y Abd-El-Aziz, como veremos en el siguiente apartado.

En este mismo sentido, por poner otro ejemplo y continuar con el panorama general de la masonería española en estas fechas, el caso de los componentes judíos de la logia Lixus n. ${ }^{\circ} 23$ de Larache, una de las dos únicas ciudades durante los años 20 con logias masónicas en el protectorado español, contará entre sus integrantes con 4 judíos de 10 miembros totales en 1922, 8 de 28 para 1924 y 1 de 20 para 1930. Es decir, con un total del 22\%. Esta disminución en los años 30 se debe a la disgregación de la logia en dos talleres, Lixus n. ${ }^{\circ} 446 \mathrm{~B}$

\footnotetext{
33 El GOM (1890-1892) y la primera GLRM (1923-1927) se constituyeron en Tánger.

${ }^{34}$ Moulay Hassan, 1918, CDMH, SE Masonería A, legajo 770, exp. 5.
} 
y Perseverancia n. $^{\circ} 70$, la primera perteneciente al GOE y la segunda a su rival en estos momentos, la Gran Logia Española (GLE). Es decir, los judíos de Lixus n. ${ }^{\circ} 23$ pasaron casi en su totalidad a la nueva logia de Larache y ninguno quedó en su antiguo taller, y así continuará durante la II República puesto que Perseverancia albergará a la mayoría judía de la ciudad mientras que su vecina apenas tendrá representatividad de este grupo. Los datos de Cabo Espartel y Tetuán n. ${ }^{\circ} 64$, las otras dos logias del protectorado español, contarán en 1930, pues no disponemos de datos anteriores, en torno a un $20 \%$ de judíos. Una cifra que, como vemos en la última gráfica (III), será representativa de la nueva tendencia de los miembros masones de las logias españolas.

Siguiendo los datos del último gráfico (III), durante la II República se constituirán nuevas logias por el territorio correspondiente al protectorado español, en detrimento de la ciudad internacional tangerina y la zona francesa. Sin embargo, estas 10 logias, fundadas entre 1931 y 1932 y herederas de Lixus, Tetuán y Cabo Espartel, tendrán una composición menos propicia en cuanto a la cuantificación de judíos, estando más representadas por funcionarios civiles y militares españoles. El porcentaje de judíos osciló entre el $4 \%$ y el $26 \%$ declinando la balanza hacia las logias del protectorado francés y la siempre constante Morayta de Tánger, cuya cifra se mantuvo en torno al 50\%.

No obstante, estableciendo cálculos aproximativos, anualmente se constatarían entre 50 y 90 judíos en todas las logias españolas del periodo. En la parte española, destacaría Tetuán y Larache y, en menor grado, Alcazarquivir. Las ciudades mencionadas coinciden en ser precisamente las que integran un mayor número de comunidades judías en estas fechas ${ }^{35}$. Por otro lado, si tenemos en cuenta los cargos ocupados por los judíos en el seno de las logias, obtendríamos una estimación bastante más significativa, dado que muchos de ellos ostentaron puestos relevantes en la $\mathrm{GLRM}^{36}$, o bien fueron venerables ${ }^{37}$, vigilantes, secretarios y oradores en los talleres a los que pertenecieron. Pero este hecho también formó parte de las épocas precedentes. Morayta y Samuel Güitta, por ejemplo, siempre tuvieron algún judío como venerable maestro ${ }^{38}$, además, solían ser los mismos directivos y responsables de las asociaciones hispano-hebreas y formaban parte de las familias de comerciantes más importantes de la ciudad tangerina. Algunos, incluso, tenían la nacionalidad española o gozaban de su protección ${ }^{39}$.

35 OJEDA MATA, 2013: 193-194.

${ }^{36}$ Isaac Beneich fue gran limosnero (1932), Alberto Obadía gran tesorero (1934).

37 Elie Kadosh de Fez-Lumière, Josué E. Pinto en Fiat Lux y Samuel Choukron en Oriente. En $L u z$ fue primer vigilante y miembro fundador, Isaac Ederi, etcétera.

${ }^{38}$ Samuel M. Güitta fue venerable de Morayta, delegado del GOE en Marruecos; el director de la AIU de Casablanca fue dignatario de Samuel Güitta, etcétera.

39 Es difícil aún establecer un porcentaje concreto. En el siguiente apartado abordaremos este tema.

Hispania, 2019, vol. LXXIX, nº 261, enero-abril, págs. 189-219, ISSN: 0018-2141, e-ISSN: 1988-8368

https://doi.org/10.3989/hispania.2019.007 
GrÁfico III. Porcentaje de judíos en las logias españolas de Marruecos (1931-1936)

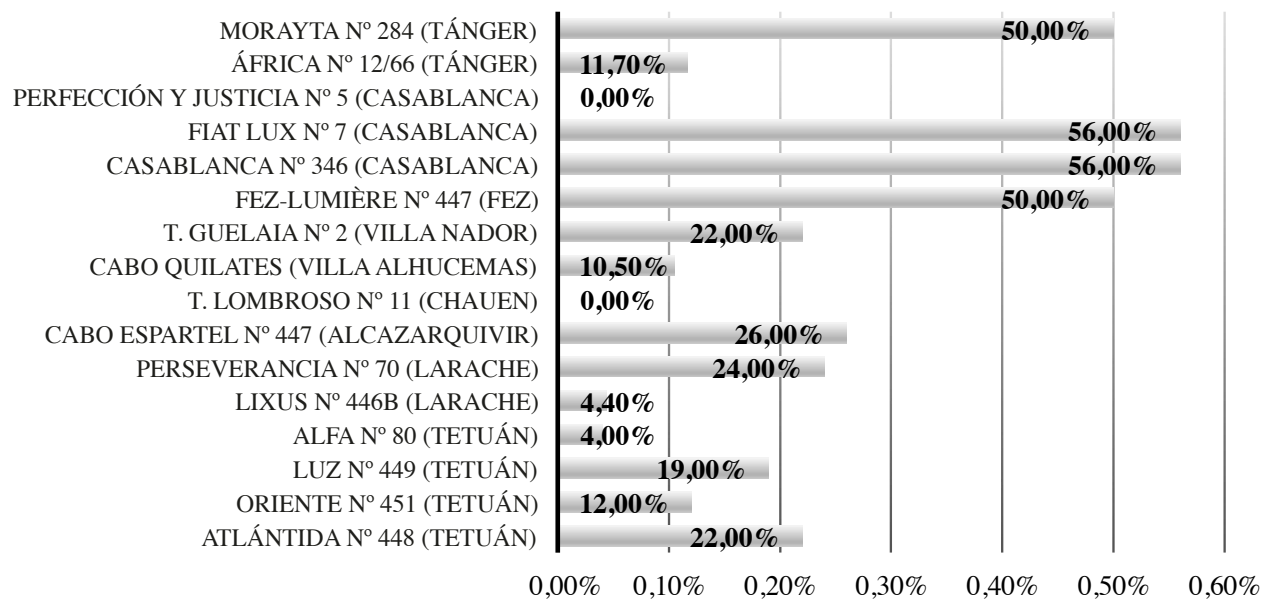

Fuente: creación propia.

Por último, no podemos obviar que el grueso de los integrantes judíos de las logias declinará la balanza desde los años 20 a las logias situadas en la zona francesa, mientras que, en el protectorado español, a excepción de Tánger y ya sin la misma importancia numérica y masónica, el porcentaje será menor, con un total de $170(17 \%)$ durante toda la etapa republicana. La situación de inestabilidad política y económica de España responde a este balance, pero también se debe al movimiento fascista y antisemita que resurgía con fuerza en Europa y en España. Los sectores más conservadores, abanderando el antisemitismo y contrarios a la masonería, empezaron a perseguir a los masones y a los judíos en el protecto$\mathrm{rado}^{40}$. Isaac Benitah Amselem expresa sus quejas hacia estas persecuciones en Alcazarquivir en 1933 en un interesante trabajo donde arguye que si bien «al cambio de régimen en España se les hizo a todos los hebreos un llamamiento (...) por la libertad de culto y religión», en esos momentos «cierto(s) elemento(s) que dicen ser nacionalistas», entiéndase aquí, nacionalistas españoles y monárquicos, «marchaban en desbandadas al Barrio Judío pegándoles a los hombres y a los niños... $\rangle^{41}$. La II República en Marruecos, ciertamente, no se reconocería por la libertad de expresión, de reunión o de culto que establecía su constitución.

40 PAZ SÁNCHEZ, 2006: 343-345.

${ }^{41}$ En el texto añade también que las persecuciones se debían a «la mayoría de algunos altos cargos que hoy funcionan al frente de las muchas Dependencias del Estado en nuestra Zona, muchos son amantes a la derrocada monarquía». Las persecuciones en contra de los Israelitas en Marruecos, Villa Alhucemas, 14 de mayo de 1933. Expediente masónico, CDMH, SE Masonería A, legajo 94, exp. 18. 
Pese a ello, las comunidades judías, sobre todo de Tetuán y Larache, desde sus posiciones activas en las logias, nos indican que su participación de los ideales masónicos y republicanos seguían siendo la tónica dominante. Pero para abordar la complejidad de esta situación debemos aproximarnos a las vicisitudes del encuentro hispano-marroquí en la masonería española.

\section{UN DISCURSO MULTIFORME}

Basta con observar las cifras del componente judío en las logias magrebíes expuestas en el apartado anterior para confirmar que el discurso construido por la masonería norteafricana provino, en gran parte, de su presencia en ellas. Así, judíos y españoles, más o menos igualados, según la zona y de forma conjunta, laborarían en pro del discurso, del ideal masónico que defendían. En este último apartado intentaremos aproximarnos al encuentro cultural en los espacios de las logias, pues serán el laboratorio que mejor defina las incongruencias entre el discurso masónico, su praxis y las identidades en juego. Interacción que se convertirá en la prueba definitiva de que las intenciones de ambos grupos no siempre giraron en torno al ideal que defendían. Y es que los preceptos masónicos, la identidad común legitimada por el canon colonial, la situación pluricultural norteafricana, pero también la apropiación de «Occidente» por parte de los judíos marroquíes, su naturalización como españoles, su propio imaginario y, por consiguiente, su propia resignificación identitaria, serán los factores que definirán y extralimitarán el discurso y la praxis de la masonería. Dividiremos estos elementos en cuatro partes que, aunque relacionadas, facilitarán la narración.

\section{Génesis y praxis de la masonería}

En general, durante todo el recorrido histórico de las logias españolas en Marruecos, la materialización de su discurso se transmutaría desde la convivencia pluricultural y plurirreligiosa presente en Marruecos hasta los proyectos y acciones conjuntos para alcanzar su ideal. Si bien hemos comprobado la expansión masónica por todo el territorio y la existencia de una convivencia real en los talleres, debemos añadir a ello los proyectos labrados para su fin. Así, desde principios del siglo XX, aparecen en Tánger diferentes centros fundados en nombre de la masonería española: una biblioteca pública, una escuela de niñas, un centro de enseñanza laica llamado «Fiat Lux» ${ }^{42}$, la constitución de

\footnotetext{
${ }^{42}$ FERRER BENIMELI, 14 (Madrid, 1992): 75-89.
} 
la logia obrera denominada también con dicho título - después corregido por el de «Francisco Ferrer» en honor al creador de la Escuela Moderna-, el establecimiento de diferentes asociaciones hispano-hebreas, etcétera.

El primer ejemplo representativo de esta materialización, la biblioteca pública solicitada por Abd-El-Aziz en 1905 a su obediencia, marcan la intención real del resto de iniciativas. Bajo el pretexto de «la falta de cultura y atraso en que se encuentra Marruecos» y con el fin de «dar a conocer a estos habitantes lo sublime de la Orden Francmasónica», y «puesto que educar, instruir y moralizar a los hombres, es la principal tarea de la francmasonería $\rangle^{43}$, bajo tales premisas, la principal lucha de los masones tangerinos era, en realidad, contra el fanatismo religioso de la Iglesia católica ${ }^{44}$ y la lucha por la separación de este organismo del Estado:

... para obtener la felicidad del hombre, es imprescindible que no dominen sobre los pueblos las creencias religiosas, sino que todos ellos profesen las mismas ideas, fundamentadas en la creencia de un principio regulador e infinito de todo cuanto existe y, en las máximas de la moral universal (...): haz a los otros lo que quieras que hagan contigo ${ }^{45}$.

Esto último, además de ser una inferencia compartida por las religiones universales, es una acomodación cultural de la modernidad ilustrada y sus valores cristianos inherentes, reproducida y adaptada al código moral masónico norteafricano. Encierra, por tanto, el deseo y la necesidad de que un territorio plurirreligioso esté regido por normas y éticas conciliadoras de la diversidad de cultos $y$, en ningún caso, beneficiadoras de uno y perjudiciales para el resto. Y más si los cultos implicados han estado históricamente perseguidos como es el caso de los judíos, en cuyo imaginario descansaban los sucesos de la expulsión de Castilla, las condenas de las distintas monarquías hispánicas y su marginación en Marruecos por parte de los musulmanes. En la situación contextual que nos ocupa, el papel «neutral» era asumido y practicado únicamente por la masonería, pues hasta la II República no se formularán en el Estado español leyes al respecto. Las logias, en ese sentido, se convirtieron en el receptáculo de los ideales frustrados del imaginario identitario judío. Por poner un ejemplo de muchos, Isaac Benitah en un trabajo presentado para Cabo Quilates en 1933, establece que «aunque después de muchos siglos no se ha logrado borrar el recuerdo de aquel desacierto de los Reyes Católicos, que expulsaron del suelo patrio a esos miles de judíos», la ayuda que «los israelitas» prestaron a los españoles al principio de la

\footnotetext{
${ }^{43}$ Propuesta del GONE, 7/12/1898, CDMH, SE Masonería A, legajo 770, exp. 8.

${ }_{44}$ Folleto del proyecto, 1/12/1898, CDMH, SE Masonería A, legajo 770, exp. 8.

45 Resolución, 14/05/1905, CDMH, SE Masonería A, legajo 770, exp. 8.
} 
colonización fue «valiosísima», debido a su desconocimiento de la «psicología del indígena». Sin embargo, matiza

... otra cosa hubiera sido la penetración y función de España en Marruecos si desde el primer día hubiera sabido ir en una estrecha inteligencia con los Israelitas del país como existen en el Protectorado y la Argelia de la República Francesa y las Colonias Inglesas. Olvidemos todos los males pasados y todos unidos tenemos el deber sagrado de luchar por la Paz para fundir como buenos hermanos a todos los españoles Musulmanes e Israelitas por la libertad de la justicia y el trabajo para mayor engrandecimiento de nuestra amada República ${ }^{46}$.

El error de los diferentes regímenes españoles había sido, partiendo de esta retórica, no contar con el apoyo judío, sustancial para hacer del Magreb una parte más de España, donde los expulsados de la patria conservaban, incluso, «el idioma español». Por consiguiente, su presencia en las logias y su misión a través de ellas era paliar estas deficiencias. De todos modos, a pesar de las políticas pluralistas y liberales que prometía la Constitución de 1931, el recién instaurado régimen tampoco cumpliría tales expectativas, relegando a la masonería como único organismo capaz de ofrecer las libertades y los objetivos deseados:

... cuando logre que en el sentimiento humano florezca este lema de LIBERTAD, IGUALDAD Y FRATERNIDAD», cuando conseguido esto, la masonería de por cumplida su ingente obra, entonces, solo entonces, persistirá en el Universo, como única Religión: la RAZÓN; como única raza: la HUMANIDAD; como único Templo: el MUNDO ${ }^{47}$.

Con todo, eliminar «la perniciosa influencia que ejerce el clericalismo» ${ }^{48} \mathrm{y}$ laborar en pro de la educación laicista, cosmopolita, universal... parecen ser objetivos únicamente realizables por la masonería. Pero también parecen ser los primeros elementos de conciliación entre españoles y judíos en las logias. Curiosamente, a pesar de que se propondrán desde los talleres numerosos proyectos educativos con estas bases, a pesar de que se realizarán constantes acciones en contra del clericalismo y contrarias al fascismo europeo y español que ya había cometido sus incursiones en el protectorado, a pesar de todo ello, pocos logros llegaron a ver la luz ${ }^{49}$. Y aquellos alcanzados carecieron de sentido a raíz del golpe de estado militar de 1936 que transformó sustancialmente las relaciones hispano-judías tergiversándolas en su mítico complot.

\footnotetext{
${ }^{46}$ Expediente personal, 20/10/1933, CDMH, SE Masonería A, legajo 94, exp.18.

47 S. Cohen, CDMH, SE Masonería A, legajo 122, exp. 1.

48 Abd-El-Aziz, CDMH, SE Masonería A, legajo 770, exp. 8.

49 AGUIAR BOBET, 2017a: 493-507.
} 


\section{De la acomodación a la naturalización}

La constitución de la biblioteca pública en Tánger en 1905 fue obra del venerable maestro de Abd-El-Aziz, Joseph J. Bengio, elegido por «ser este hermano entre la colonia israelita considerado como apto para desempeñar dichas funciones y ejercer entre ellos alguna influencia por ser muy allegado a la familia del Gran Rabino» ${ }^{50}$, y por el que, además, muchos judíos se iniciaron en ella. Sin embargo, otros componentes de la logia, tanto judíos como españoles, acusarán a Bengio de abuso de poder y de irregularidades masónicas, entre otras cosas, por la iniciación de ciertos individuos de «situación dudosa» ${ }^{51}$, votaciones antirreglamentarias, disminución de las obras de caridad, etcétera. Tal vez, las fricciones mencionadas no pasan de ser individuales, pues muchos venerables fueron acusados de irregularidades a lo largo de la historia de la institución. No obstante, junto a las denuncias que destacaban los firmantes consta también un «baile masónico ${ }^{52}$ realizado en la casa de una familia de grandes comerciantes tangerinos. En el evento, que tenía el objeto de recaudar dinero para «los pobres de la localidad sin distinción de creencias», se exigía a los organizadores hacer uso de «traje europeo» en detrimento de la vestimenta tradicional marroquí, pues «se trataba de un baile en el que estarían presente lo más escogido de la ciudad tangerina», evitando así malas impresiones «a las miras del público» ${ }^{53}$.

Esto nos lleva a considerar la importancia otorgada en las logias a la «asimilación» o a la «apropiación» de la cultura dominante a través de las normas y valores sociales indicativos de «civilización» $\mathrm{y}$ «modernidad», sobre todo teniendo en cuenta la condición de enclave internacional, económico y comercial de la ciudad en que se propuso y realizó el baile. Y, por otro lado, nos lleva a deliberar que, los individuos aspirantes a la iniciación en las logias debían poseer una serie de requisitos imprescindibles. Es decir, no se trataba de que debiesen aceptar o asumir los principios masónicos, que, en definitiva, eran los principios de la Ilustración y la modernidad occidental, se trataba de que ya debían tenerlos integrados, al menos en parte ${ }^{54}$.

No es extraño, por ello, que los judíos masones formasen parte, en su gran mayoría, de la élite de su comunidad, como veremos a continuación, ni que fuesen los masones con más poder adquisitivo en contraste muchas veces con

\footnotetext{
${ }^{50}$ Resolución, CDMH, SE Masonería A, legajo 770, exp. 8.

${ }^{51}$ Memoria 1899, CDMH, SE Masonería A, legajo 770, exp. 8.

${ }^{52}$ El evento fue censurado por miembros del taller y por otros sectores tangerinos al considerarse un medio de financiación de la masonería, $\mathrm{CDMH}$, SE Masonería A, legajo 770, exp.

${ }^{53}$ Carta al GONE, 16/03/1899, CDMH, SE Masonería A, legajo 770, exp. 8.

${ }^{54}$ BEAUREPAIRE, 2009: 3-4.
} 8. 
los españoles, como también veremos. Y tampoco lo es que un gran número fuesen, a su vez, los miembros directivos de las asociaciones hispano-hebreas o, incluso, de las Escuelas de la Alianza Israelita Universal (AIU). Y desde luego tampoco es anecdótico que prácticamente en su totalidad fuesen educados en los centros que auspiciaba la Alianza, tal y como confirman sus expedientes personales ${ }^{55}$. Es más, en tales documentos siempre se refleja el alto nivel de estudios y el conocimiento de varios idiomas: hebreo, francés, árabe y español principalmente. También, por poner otro ejemplo, este aspecto se podrá observar en la mayor concesión de becas a estudiantes judíos, en detrimento de los musulmanes marroquíes por tener los primeros más y mejores posibilidades de éxito ${ }^{56}$.

Sin embargo, la asimilación presenta algunas ambivalencias discursivas en la praxis masónica. La logia Ciencia y Libertad n. ${ }^{\circ} 288$ de Tánger, en una carta remitida al GOE el 10 de septiembre de 1906, expresaba «la serie de vejámenes que soporta entre la resignada raza hebrea aquellos de sus miembros que por circunstancias especiales no ha podido cobijarse bajo la bandera de una nación civilizada, figurando en consecuencia como súbditos marroquíes». Y, continúa,

... los hebreos no protegidos, están a merced del primer advenedizo, y no sola-
mente son privados con frecuencia de la libertad, impidiéndoles así sustentar a sus
familias, sino que hasta los bienes que poseen están en constante peligro, pues a
cada momento se les despoja de ellos por los secuaces del mal llamado gobierno
marroquí, sin que nadie preste atención a las protestas que formulan ${ }^{57}$.

Esto nos lleva a reconsiderar el número de judíos masones nacionalizados o protegidos españoles, marroquíes o de cualquier otra potencia, también como referencia esencial para determinar la condición sociopolítica de los miembros. No todos los cuadros lógicos contienen tales referencias, ni tampoco los expedientes personales y otros documentos, pero podemos poner, como ejemplo, el cuadro lógico de Morayta de 4 de mayo de 1906, en el que aparecen de los 15 judíos contabilizados, 4 con nacionalidad española, siendo Samuel Güitta uno de los susodichos; un brasileño y el resto, marroquíes. Si bien es verdad que una parte de los integrantes son protegidos españoles naturalizados, otros no se «benefician» de ese estatus, lo que nos lleva además a definir a las logias como puntos de encuentro clave no solo entre iguales o «asimilados», sino entre protectores y protegidos, donde los judíos marroquíes, muchos de ellos de origen sefardí, guardaban el deseo de obtener la nacionalidad española y, con ello, las ventajas propias de la metrópoli en la balanza colonialista, utilizando para ello

\footnotetext{
55 GONZÁLEZ GONZÁLEZ, 2013: 73-92.

56 AGUIAR BOBET, 2017a: 493-507.

${ }^{57}$ Ciencia y Libertad al GOE, 10/09/1910, CDMH, SE Masonería A, legajo 771, exp. 2.
} 
los preceptos de «igualdad»y «fraternidad» con que les amparaban las logias. Más adelante, durante la República, este objeto seguirá formando parte de las propuestas de las logias que laborarán por la nacionalización de los sefardíes ${ }^{58}$.

Respecto al judío brasileño, debemos mencionar la constante diáspora comercial entre el norte de África y Argentina, Brasil y Venezuela, los destinos predilectos del éxodo judeo-marroquí, especialmente entre sefardíes ${ }^{59}$. Éxodo que, además, se incrementará después de la II Guerra Mundial. De este modo, algunos de los masones judíos que integran las logias norteafricanas tendrán también un origen americano, reforzando así los lazos intercomunitarios entre las dos orillas del Atlántico, tal y como advertíamos en otro trabajo ${ }^{60}$.

Por tanto, otro de los elementos que parece configurar la praxis y el discurso masónico es la instrumentalización de las logias por parte de los judíos, tanto para conseguir ciertos fines (la nacionalidad española), como influencia social y voz política (la lucha contra el fascismo y el anti-semitismo) en un espacio que, además de los beneficios igualitarios y fraternales de la liturgia masónica, ofrecía la posibilidad de la sociabilidad y solidaridad internacional y, además, el apoyo entre sus miembros. Apoyo que, también, se convertirá en el favor de ciertos grupos (los judíos) respecto a otros (los musulmanes). Por poner otros ejemplos que sustentan este hecho, cabe mencionar la denuncia que desde las logias tangerinas se realizó a propósito de la muerte de un joven judío, hijo de un componente de Morayta, a manos de un musulmán en Tánger en $1912^{61}$ y que, más allá de ser un lazo de solidaridad, reflejaba la inflexión sufrida por la población marroquí a través del régimen de protecciones. Los judíos no solo denunciaron el hecho en las logias, sino que motivaron una respuesta judicial de los tribunales españoles por medio de la notificación del suceso a su obediencia, el GOE, pues el proceso se veía comprometido por el hecho de que el musulmán incriminado era súbdito holandés y exigía el procedimiento debido por medio de su embajada. El sistema de protecciones envenenó las relaciones intercomunitarias ya que «solo favoreció a un grupo de élite y convirtió a los judíos humildes en chivos expiatorios del recelo musulmán frente a los abusos de la élite protegida ${ }^{62}$. Pero aún más, el peso de las realidades clientelares trascendió las fronteras religiosas y de las comunidades étnico-culturales y ante conflictos penales, las partes implicadas apelaban a la jurisdicción del país que le protegía ${ }^{63} \mathrm{o}$ a aquellas instituciones, como la masonería, que podrían favorecerles.

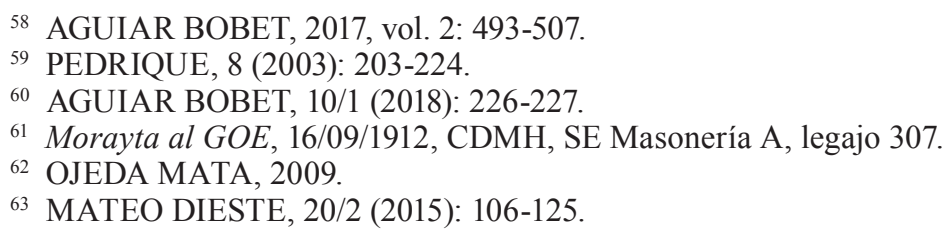


Por último, en esta instrumentalización de las logias, cabe destacar las quejas, más o menos constantes de las logias tangerinas en torno a los años 20, por la presencia de la masonería francesa en dicha ciudad, a la que se acusaba de imperialismo desmedido e injustificado:

A pesar de nuestra posición geográfica, de nuestra superioridad numérica, de la difusión de nuestro idioma, hablado hoy hasta por los indígenas musulmanes, no solo de la ciudad, sino hasta de los poblados de los alrededores de Tánger y sostenido desde hace varios siglos por los israelitas sefardíes venidos de España en el siglo XV, el desmedido apetito colonial de cierta nación, quiere hacer tabla rasa de todo y recurre al desprestigio y la calumnia, para llegar al logro de su ambición imperialista ${ }^{64}$.

El canon colonial y el ideal masónico están del todo representados en este párrafo. Pero, más que eso, se observa cómo los masones españoles, en el juego de la soberanía imperialista en una ciudad con jurisdicción internacional, hacen uso del que consideran «su derecho legítimo» en la colonización africana, sustentándose en la relación y la herencia histórica con los sefardíes del territorio. Las fronteras étnico-religiosas e, incluso, identitarias, se difuminaban en función de los intereses personales, las redes de influencia, el destino de las comunidades y de la nación española. Los conflictos de origen individual tendieron a canalizarse en forma de conflictos intercomunitarios, aunque muchas veces se apelara a la fórmula de la común identidad ${ }^{65}$.

\section{¿Una lucha de «razas»? Logias judías y logias cristianas}

Si bien los límites entre culturas se presentan difusos en el seno de las logias y van desde la conciliación por intereses comunes, la asimilación y aceptación de los preceptos de la modernidad que defiende la masonería, así como de las barreras conceptuales y socioculturales del canon colonial africanista, diversos hechos y narraciones de los masones del protectorado parecen cuestionar esta «acomodación» cultural pactada.

En 1906 el Capítulo Fiat Lux de Tánger denunciaba a la logia Morayta por irregularidades masónicas. La causa era la iniciación casi exclusiva del «elemento hebreo». En una carta del capítulo al GOE mencionaba esta condición pues dicha logia solo contaba con «cinco cristianos» y «viene tratando de ejercer una influencia y supremacía dominante sobre todos los demás hermanos» ${ }^{66}$. Los dignatarios del capítulo, en su mayoría miembros de Abd-El-Aziz,

${ }^{64}$ Abd-El-Aziz a Constante Alona $n .^{\circ} 3$ de Alicante, 7/07/1920, CDMH, SE Masonería A, legajo 770, exp. 8 .

${ }_{65}$ MATEO DIESTE, 20/2 (2015): 106-125. MARTÍN CORRALES, 2013: 93-110.

${ }^{66}$ Capitulo «Fiat Lux» al GOE, 23/09/1906, CDMH, SE Masonería A, legajo 771. 
especificaron que las razones de este conflicto estaban determinadas por la iniciación de individuos «indignos», especialmente «hebreos», que habían sido rechazados en otras logias, y por la realización de trabajos anómalos que estaban convirtiendo a la masonería tangerina en «un lucro comercial». Hechos que, según sus denunciantes, sucedían desde que Samuel Güitta fue elegido como venerable del taller acusado. Como contrapartida, los miembros de Morayta amenazaron con desligarse y dimitir de sus cargos directivos en los centros culturales y educativos fundados por las logias tangerinas (el centro de enseñanza laico Fiat Lux, el periódico del mismo nombre, las escuelas y la biblioteca), insistiendo, además, que les borrasen como suscriptores. Esto, más que un gesto simbólico, era una guerra declarada al proyecto social de la masonería y a la propia masonería, que prácticamente estaba sustentada en este periodo por los judíos de Morayta. Es más, alegaban en la correspondencia mantenida que «era la mejor logia de todas por la posición social y elementos de vida de sus hh.:» puesto que, además, mantenían el alquiler de la casa que utilizaban de templo y de todos los locales dedicados a las obras sociales. Sin embargo, el contrataque de Morayta también abordaba la cuestión antisemita de parte de la población: el autor de la carta, correspondía a la acusación étnico-religiosa cuando establecía que

... en realidad no es más que una oposición enérgica y dominante del elemento hebreo sobre el cristiano, por querer en todo, tan crecidos como están, ejercer una influencia general dominadora sobre todos los demás elementos ${ }^{67}$.

Finalmente, el GOE no tomó represalias, al contrario, apoyó al taller incriminado pues «ellos son los más, tienen más dinero y están amparados por ese Oriente» ${ }^{68}$, y Abd-El-Aziz culpó a varios de sus componentes de haber realizado la denuncia sin consultar con el taller ${ }^{69}$. El resultado fue que Morayta continuó sus trabajos pero de forma autónoma respecto al capítulo y a otras logias, con excepción de las fundadas por ellos. No es de extrañar que, en 1907, el mencionado capítulo en otra carta al GOE concluyese que, en Tánger solo existía

... una lucha de razas ya bastante confirmada, pues se desea la absoluta separación de cristianos y hebreos, como podréis comprobar por el crecido número de ingresos de estos últimos en las logias Morayta y Ciencias, que solo admiten hebreos, en contraposición de las logias Fiat-Lux y Abd-El-Aziz, en las que el elemento que predomina es el cristiano ${ }^{70}$.

${ }^{67}$ Capitulo «Fiat Lux» al GOE, septiembre-octubre 1906, CDMH, SE Masonería A, legajo 771.

${ }_{68}$ Capitulo «Fiat Lux» al GOE, 19/06/1907, CDMH, SE Masonería A, legajo 771.

${ }^{69}$ Morayta al GOE, 25/10/1906, CDMH, SE Masonería A, legajo 307.

70 Capítulo «Fiat Lux»al GOE, 19/06/1907, CDMH, Se Masonería A, legajo 771. 
La tendencia, en la década siguiente, esta vez en Casablanca, fue la misma. Como ya mencionamos, el número de masones judíos en la logia que ostenta el nombre de la ciudad fue sustancialmente menor que el de su vecina Samuel Güitta, con un $40 \%$ de diferencia entre ambas. Además, sus relaciones nunca fueron favorables y existen numerosas quejas al GOE de la primera por las actividades de su vecina: no comunicaban las iniciaciones ni los trabajos realizados $^{71}$. Sin embargo, este hecho contrasta con que, precisamente, Samuel Güitta propuso la convergencia de los talleres españoles en una obediencia regional $^{72}$. Y, también por la tendencia del GOE, igual de significativa, de omitir las quejas por tales irregularidades y, al contrario, favorecer a las inculpadas. Esto nos lleva a destacar que la participación judía en las logias, sobre todo si se trataba de las élites que la componían, era utilizada por la masonería para contar con el apoyo económico, colonial e internacional del grupo en cuestión. Y así se establece en la memoria de 1917 del GOE donde certifica que Morayta «seguirá haciendo la labor que durante muchos años se había impuesto: recoger las aspiraciones de la colonia hebraica tangerina, y servir de órgano de relación entre ella y las de América y Oriente ${ }^{73}$ ). De todos modos, diez años más tarde, el GOE pondría fin a la autonomía de la logia Samuel Güitta, pero la respuesta de este taller será solicitar auspicios a la obediencia nacional contraria, la $\mathrm{GLE}^{74}$.

En cualquier caso, debemos preguntarnos si las desavenencias intercomunitarias fueron realmente representativas o no, puesto que en casi todos los talleres hay, en mayor o menor medida, presencia judía. Sí es verdad que existe una tendencia en las iniciaciones o afiliaciones de los judíos a las logias con mayor número de miembros de su grupo, pero esto es un comportamiento habitual entre individuos que comparten creencias, culturas, orígenes... No obstante, sin ser una excepción a la regla, hubo también otros judíos para los que la masonería estuvo determinada por los lazos educativos y no tanto étnico-religiosos. En 1931, por ejemplo, la correspondencia entre las logias Lixus y Perseverancia de Larache, demuestra que Amram Amselem prefirió iniciarse en la primera de las mencionadas, que no contaba con ningún judío entre sus filas, porque en ella se encontraba «su maestro de primera enseñanza Matamala, y su compañero de Madrid Martínez Barrios $\left.{ }^{75}\right\rangle$. Miguel Matamala era profesor de la Escuela Hispano-Hebrea, profesión que le convertía en uno de los primeros vínculos educativos que los jóvenes judíos tenían con España y los españoles. En estas escuelas, se fomentaría la instrucción del español como segunda

\footnotetext{
71 Casablanca al GOE, diciembre 1915, CDMH, SE Masonería A, legajo 376, exp. 1.

72 S. Güitta al GOE, 8/01/1923, CDMH, SE Masonería A, legajo 377.

73 VI Asamblea Nacional, GOE, 17/05/1927, CDMH, SE Masonería A, legajo 683.

${ }^{74}$ Memoria GOE, 1927, CDMH, SE Masonería A, legajo 683.

75 Expediente personal, CDMH, SE Masonería A, legajo 29, exp.15.
} 
lengua en detrimento del peso que la francesa adquiría en las escuelas de la AIU. No obstante, lo que nos interesa del caso es que en las logias no existía una lucha de «razas» per se, o al menos no es lo que deducimos de la documentación consultada. Lo que había eran identidades ambivalentes, confusas y multiformes, producto de la «diglosia cultural» — término que definiremos más abajo - y del encuentro hispano-judío en un contexto colonial y plural que ambos entendían como suyo por derecho histórico. Y la mención a Madrid y a Martínez Barrios como argumentos determinantes, son un gran reflejo de ello.

\section{El «último eslabón»: «judeidad» y masonería}

Para terminar de configurar los elementos que caracterizaron y extralimitaron el ideal masónico norteafricano debemos considerar si, además del pasado común, de los intereses comunitarios y de la oportunidad que la masonería ofrecía a los implicados para enmendar los errores de la política española, existió alguna relación más taxativa entre la masonería y los judíos que pueda explicar su presencia constante y activa en las logias. Pero para ello debemos remontarnos a dos de los puntos de inflexión de la reconstrucción identitaria de los judíos y «lo judío»: las escuelas de la AIU y el auge del sionismo.

La AIU aparecía en Francia en 1860 con la finalidad de prestar apoyo institucional a las comunidades judías minoritarias que se encontraban en situación de desigualdad frente al resto de las poblaciones. Era el medio modernizador por el que podrían adquirir una educación más europeizada y acorde con los cánones educativos y científicos del momento. Pero también era el medio para adoptar los valores europeos y para (re)interpretarse si bien principalmente en el contexto colonial, en el marco social de los colonizadores europeos. De hecho y tal y como consta en sus expedientes, fueron estos judíos educados en los valores franceses, a pesar del origen sefardí de algunos, quienes nutrieron en un porcentaje a su favor los cuadros de las logias españolas durante todo su recorrido histórico. Y, además, fueron quienes con igual o más fuerza, defendieron su pertenencia a una nación "civilizada» y emancipadora, atribuyéndose la misión de «liberar» a sus correligionarios del yugo musulmán y de las supersticiones del pasado ${ }^{76}$. Aunque la aparición de la AIU acontece mucho antes del periodo colonial, el discurso sionista y «judío», pero también cosmopolita, se iría incrementando con el transcurso de los años hasta el punto de que, después de la conformación del protectorado, la identidad de la comunidad judía en Marruecos oscilaba entre el pasado común compartido y el sentimiento de pertenencia a su grupo etno-religioso.

\footnotetext{
${ }^{76}$ ZYTNICKI, 2013: 59-73.
} 
La masonería norteafricana, ligada a los principios cosmopolitas, universalistas y tolerantes de esta misma modernidad, pero también vinculada sin reservas a su identidad nacional española, era el espacio idóneo donde los judíos podían ejercer el doble juego entre cosmopolitismo y nación, puesto que también en la orden se vinculaban, en paralelo, los preceptos nacionales y coloniales de la patria española y los otros oriundos de la ilustración. En este sentido, por tanto, los orígenes ideológicos de esta masonería estuvieron directamente relacionados con la resignificación de «lo judío» o la judeidad. Este concepto, según la definición establecida por Judith Butler es, en sí mismo, anti-identitario e implica el establecimiento de relaciones éticas con los no judíos, representado por el principio de «cohabitación» como norma de sociabilidad ${ }^{77}$. En esta «invención de lo judío» ${ }^{78}$ como resaltan otros autores, el cosmopolitismo y el respeto o tolerancia multirreligiosa defendida en las logias se entremezclaban con las exclusiones históricas y las diásporas consiguientes que hacían de su condición un «pueblo sin patria» en el «eterno retorno» de su historia. Condición que, con la aparición de la Alianza, se transformaría en anti-identitaria. La AIU, a pesar de ser un producto «made in Europa», era una institución universal que, como su nombre indica, iba más allá de la nacionalidad de sus miembros a pesar de que estos poseyesen una nacionalidad «accidental» ${ }^{79}$. Lo mismo que para ellos significaba la masonería.

$\mathrm{Y}$ esto nos lleva a confirmar que los judíos, en su ingreso en las logias, no asumen ningún discurso nuevo, pues el ideal que defendían en las logias del protectorado estaba ya incorporado en su reconstrucción identitaria. Los judíos, ni como individuos ni como comunidad, se pueden comprender, por tanto, como algo extrínseco, ajeno al proyecto y el ideal masónico que debe ser asumido, sino que ellos mismos son significantes de su retórica. Y también, por supuesto, de las barreras y fricciones conceptuales, étnico y socioculturales que presenta. En uno de los trabajos leídos durante la celebración del VIII Centenario de Maimónides en la ciudad de Larache en $1935^{80}$, Rafael Pérez de Perseverancia destaca la figura del erudito cordobés como emblema esencial «de la historia errante del pueblo hebreo, símbolo de la dispersión en que el pueblo hebreo repartido a través de todas las naciones ha dejado en ella los mejores tesoros de su espíritu», a la vez que concilia este principio con la pertenencia de Maimónides «a España por su nacimiento, su primera educación, sus virtudes intelectuales y morales y por los principios de su filosofía». Razón por la cual, continúa,

\footnotetext{
77 BUTLER, 2006: 72-75.

78 SHLOMO SAND, 2011.

79 GONZÁLEZ GONZÁLEZ, 2010: 42.

${ }^{80}$ Expediente personal, CDMH, SE Masonería A, legajo 180, exp. 20.
} 
España ha acogido favorablemente desde el año 1929 la iniciativa de honrar la memoria de su hijo predilecto celebrando con actos solemnes la conmemoración del VIII centenario.

Con todo, las barreras identitarias de las relaciones hispano-judías en el encuentro masónico, más que ambivalentes, como vemos, parecen difusas. Y siempre oscilan entre los principios universales, cosmopolitas y tolerantes compartidos, sus aspiraciones internacionales como grupo étnico-religioso y la identidad común defendida por el canon colonial a través del tropo andalusí - y que se recrea con especial fuerza en la representación de Maimónides-. $\mathrm{Y}$ es que este pasado histórico también era entendido como suyo. El sabio cordobés, en este sentido, personificaba la convergencia de las tres culturas occidentales que nutrían estos talleres. Era un judío nacido en territorio andalusí en aquel lejano y distorsionado medievo ensalzado por la convivencia religiosa. Sin embargo, aquí no solo se elogia a Maimónides como símbolo judío y español, sino que, a partir de él y desde sus identidades en reconstrucción, se define «al judío» como el individuo propicio para llevar a cabo el ideal masónico. Es decir, para llevar a cabo la obra civilizatoria, la obra masónica que podía hacer de Marruecos el paraíso perfecto que implicaba su discurso.

Por último, no debemos obviar el papel del sionismo en este proceso de reconstrucciones e identidades acomodadas. Como "pueblo sin patria», este movimiento, que sería más importante en la segunda mitad del siglo XX, ofrecía la posibilidad a los judíos de configurar su propio estado-nación en un espacio simbólico y significativo como Israel. En las logias españolas los debates y discursos en torno a este movimiento son escasos y casi inexistentes, pero en el territorio francés, la preocupación de esta diáspora planteaba numerosos problemas, tal y como indican los estudios realizados por sus instancias diplomáticas $^{81}$ y por la migración efectiva resultante del movimiento. En Fez, bastantes familias judías se trasladarían a Israel durante los años $20^{82}$. Sin embargo, el grueso de la presencia judía en las logias españolas situadas en suelo francés, no desfallecería por esta circunstancia. Más, al contrario, la balanza se declinaba siempre a su favor: el porcentaje de judíos siempre fue superior a la media del total de componentes. Sea por los preceptos compartidos entre «lo judío» y la masonería, sea por los diversos beneficios económicos y políticos que las relaciones con los españoles y sus instituciones les ofrecían, o bien por el sentimiento efectivo de la identidad compartida, los judíos afiliados en las logias españolas, especialmente sefardíes, parecen diferenciar y entremezclar, según el contexto, sus lazos étnico-religiosos vinculados al judaísmo y la judeidad, sus orígenes patrios relacionados con el periodo anterior a la expulsión, y el

\footnotetext{
${ }^{81}$ Asuntos indigenas, CADAE, legajo 73CPCOM, exp. 381.

82 Asuntos indigenas, CADAE, legajo 73CPCOM, exp. 381.
} 
discurso utópico pronunciado y desarrollado en y desde las logias masónicas. No obstante, este es un tema complejo que abordaremos en futuros trabajos.

\section{EPílogo: LA «Diglosia CULTURAL»}

En definitiva, lejos de ser una «alucinación» del complot judeo-masónico del franquismo, la masonería norteafricana se configuró ideológicamente desde y por españoles, judíos protegidos, judíos sefardíes, judíos marroquíes y, en fin, el pluralismo presente en Marruecos antes y durante su colonización oficial. El discurso imperante, esto es, el ideal colonial, nació y se desarrolló desde las primeras logias constituidas en este territorio, dirigidas en comunión por todas las partes. No obstante, la presencia e interacción en las logias de los distintos grupos respondió a intereses muy diferentes de la visión complotista aludida. Amalgamados en el espacio neutral que les ofrecían las logias en cuanto a sus diferencias religiosas y socioculturales, judíos y españoles acomodaron los preceptos que la orden defendía proyectándolos al contexto colonial. Acomodación que manifestaría, por un lado, la predisposición de los judíos en la consecución de un discurso que pondría fin a sus desavenencias históricas de pueblo sin nación y excluido en su alteridad. Y, por otro, la necesidad de los grupos implicados de reconstruir y redefinir sus respectivas identidades que, no por casualidad, se encontraban en este proceso de resignificación. Y todo ello en un espacio común, performativo, favorable a los preceptos ideológicos que compartían. No es extraño, por ende, la intención inherente de las logias magrebíes de alzarse en conjunto como institución elegida para llevar a cabo la expansión colonial y la civilización de Marruecos, que, recordemos, precedió a la constitución del protectorado. Ni tampoco que defendiese, como ninguna otra, su papel regenerador de la nación basado ahora en la legítima conciliación y fraternidad entre los diferentes grupos étnico-culturales del Magreb. No es extraño, porque este era el discurso que beneficiaba a las partes implicadas, a pesar, eso sí, de sus buenas intenciones.

Pese a todo, las barreras socioculturales, económicas y políticas que impusieron los diferentes regímenes españoles al encuentro cultural hispano-judío, así como la extralimitación conceptual producto de las corrientes ideológicas que estuvieron en juego durante el periodo estudiado (filosefardismo, antisemitismo, sionismo, fascismos, entre otras), se presentan como contrapunto de la construcción de una identidad común que definía, a la vez que intentaba solucionar, las ambivalencias de su situación sociocultural y religiosa en el contexto del protectorado.

En definitiva, identidades ambivalentes, difusas, confusas, oportunistas y, en fin, híbridas, al igual que los individuos que las experimentan, nos han llevado a entender el encuentro cultural entre judíos y españoles en las logias 
magrebíes como resultado de una particular «diglosia cultural». La diglosia cultural $^{83}$, término tomado de la sociolingüística, implica la adaptación del modelo de dos lenguas o dos registros lingüísticos utilizados por las mismas personas en diversas situaciones. Es decir, los actores aquí en juego, como masones, como judíos y como españoles, expresaron a través de sus discursos todas las variables de los diferentes registros lingüísticos de su identidad multiforme. Variables que, ambivalentes, difusas, confusas, oportunistas e híbridas, salían a la superficie según el contexto. Y quizás esto explique también la armonía de algunas situaciones, pero también el conflicto de otras.

\section{Bibliografía}

Aguiar Bobet, Valeria, «La cultura de la tolerancia en el Marruecos de la Segunda República: el VIII Centenario de Maimónides» en José Miguel Delgado e Yván Pozuelo (coords.), La masonería hispano-lusa-americana, de los absolutismos a las democracias (1815-2015), Oviedo, Universidad de Oviedo, 2017a: 493-507.

Aguiar Bobet, Valeria, «La masonería española en el protectorado marroquí: un proyecto colonial y cosmopolitizador», en Ricardo Martínez, Yván Pozuelo y Rogelio Aragón (eds.), 300 años: Masonerías y Masones (1717-2017), Tomo V. Cosmopolitismo, México, Helva, 2017b: 144-168.

Aguiar Bobet, Valeria, «Redes epistolares entre la masonería de Marruecos y la americana durante la II República», REHMLAC+ [en línea], 10/1 (mayo-diciembre 2018): 53-92, doi: 10.15517/rehmlac.v10i1.32432.

Alonso García, Gregorio, «Ciudadanía católica y ciudadanía laica en la experiencia liberal», en Manuel Pérez Ledesma (coord.), De súbditos a ciudadanos: una historia de la ciudadanía de España, Madrid, Centro de Estudios Políticos y Constitucionales, 2007: 165-192.

Álvarez Chillida, Gonzalo, «Presencia e imagen judía en la España contemporánea. Herencia castiza y modernidad», en Silvina Schammah Gesser y Raanan Rein (coords.), El otro en la España Contemporánea. Prácticas, discursos y representaciones, Sevilla, Fundación Tres Culturas, 2011: 123-160.

Aziza, Mimoun, «La sociedad marroquí bajo el Protectorado español (1912-1956)», en Manuel Aragón Reyes (dir.), El Protectorado español en Marruecos: la historia trascendida, Vertiente jurídica, socioeconómico-demográfica y científico-educativa, Bilbao, Iberdrola, 2013.

Beaurepaire, Pierre-Yves, «Perception et réception des musulmans dans les loges maçonniques du siècle des Lumières», Cahiers de l'Orient [en línea], (2016), disponible en https://www.academia.edu/25058364/Perception_et_r\%C3\%A9ception_ des_musulmans_dans_les_loges_ma\%C3\%A7onniques_du_si $\%$ C $3 \%$ A 8 cle_des_ Lumi\%C3\%A8res_par_Pierre-Yves_Beaurepaire [consultado el 5 de marzo de 2018].

${ }^{83}$ BURKE, 2010: 109-112.

Hispania, 2019, vol. LXXIX, nº 261, enero-abril, págs. 189-219, ISSN: 0018-2141, e-ISSN: 1988-8368 https://doi.org/10.3989/hispania.2019.007 
Bryon-Portet, Céline, La utopie de la franc-maçonnerie, Montpellier, Presses universitaires de la Méditerranée, 2016.

Burke, Peter, Hibridismo cultural, Madrid, Akal, 2010.

Butler, Judith, «¿El judaísmo es sionismo?», en Eduardo Mendieta y Jonathan Van Antwerpen (eds.), El poder de la religión en la esfera pública, Madrid, Editorial Trotta, 2011: 69-87.

Ferrer Benimeli, José Antonio, «Preocupación de la masonería de Tánger por la educación y la paz en Marruecos (1905-1920)», Cuadernos de Historia Contemporánea, 14 (Madrid, 1992): 75-89.

González González, Irene, Escuela e ideología en el Protectorado español en el norte de Marruecos (1921-1956), tesis doctoral de la Universidad de Castilla La Mancha, Toledo, 2010.

González González, Irene, «La Alianza Israelita Universal a través del prisma del norte de Marruecos: su labor educativa (1862-1912)», en Eloy Martín Corrales y Maite Ojeda Mata (eds.), Judios entre Europa y el norte de África (siglos XV-XXI), Barcelona, Bellaterra, 2013: 73-92.

López García, Bernabé, «Los españoles en Tánger», Awraq [en línea], 5-6 (2012), disponible en http://bibliotecadigital.aecid.es/bibliodig/i18n/catalogo_imagenes/grupo. cmd?path=1007133 [consultado el 17 de julio de 2017].

Martín Corrales, Eloy, «Tensiones judeo-musulmanas en el protectorado español en Marruecos en tiempos de la II República (1931-1936)», en Eloy Martín Corrales y Maite Ojeda Mata (eds.), Judios entre Europa y el norte de África (siglos $X V$-XXI), Barcelona, Bellaterra, 2013: 93-118.

Martín-Márquez, Susan, Desorientaciones. El colonialismo español en África y la performance de la identidad, Barcelona, Bellaterra, 2011.

Mateo Dieste, Josep Lluís, «Una hermandad en tensión. Ideología colonial, barreras e intersecciones hispano-marroquíes en el Protectorado», Awraq [en línea], 5-6 (2012), disponible en: https://ddd.uab.cat/record/111989 [consultado el 8 de marzo de 2018].

Mateo Dieste, Josep Lluís, «Paradojas de la pertenencia intercomunitaria: el litigio entre un musulmán y un judío en el Tetuán colonial», Quaderns-e [en línea], 20/2 (2015): 106-125, disponible en: https://ddd.uab.cat/record/145036 [consultado el 28 de marzo de 2018].

Moga Romero, Vicente, Al oriente de África, masonería, Guerra Civil y represión en Melilla (1894-1936), Melilla, UNED, 2002.

Ojeda Mata, Maite, Sefardies en la España Contemporánea: entre nacionalismo, antisemitismo y filosefardismo, Barcelona, Bellaterra, 2009.

Ojeda Mata, Maite, «Identidades, fronteras, cruces y ambivalencias: los sefardíes en la España contemporánea» en Montserrat Ventura (ed.), Fronteras y mestizajes. Sistemas de clasificación social en Europa, América y Africa, Barcelona, Bellaterra, 2010: 57-68.

Ojeda Mata, Maite, «Sefardíes en la masonería española y represión franquista: Barcelona, Melilla y Protectorado de España en Marruecos», en Eloy Martín Corrales y Maite Ojeda Mata (eds.), Judios entre Europa y el norte de Africa (siglos XV-XXI), Barcelona, Bellaterra, 2013: 191-210. 
Ojeda Mata, Maite, «La ciudadanía española y los sefardíes: identidades legitimadoras, ideologías étnicas y derechos políticos», Quaderns-e [en línea], 20/2 (2015): 36-52, disponible en: http://www.raco.cat/index.php/QuadernseICA/article/ view/302784 [consultado el 23 de marzo de 2018].

Paz Sánchez, Manuel de et al., «La supuesta influencia político-ideológica de la masonería española a través de testimonios norteafricanos: comentarios a una visión sesgada», Aldaba, 9 (Melilla, 1987): 83-94.

Paz Sánchez, Manuel de, La masonería y la pérdida de las colonias. Estudios, Santa Cruz de Tenerife, Ediciones Idea, 2006.

Pedrique, Luisa, «La diáspora sefardí en el Nuevo Mundo», Presente y Pasado. Revista de Historia [en línea], 8 (2003), disponible en: http://www.saber.ula.ve/ bitstream/123456789/27527/1/diasporas.pdf [consultado el 30 de diciembre de 2016].

Sand, Shlomo, La invención del pueblo judío, Madrid, Akal, 2011.

Zytnicki, Colette, «El pasado de los judíos del norte de África en la literatura colonial francesa (1860-1962)», en Eloy Martín Corrales y Maite Ojeda Mata (eds.), Judíos entre Europa y el norte de Africa (siglos XV-XXI), Barcelona, Bellaterra, 2013: 59-72.

Recibido: 04/05/2018

Aceptado: 18/02/2019 